\title{
SIMS STUDY OF THE TiFe ALLOY INTERACTION WITH OXYGEN
}

\author{
V.A. Litvinov, I.I. Okseniuk, D.I. Shevchenko, V.V. Bobkov \\ V.N. Karazin Kharkiv National University, \\ Kharkiv, Ukraine \\ E-mail: bobkov@karazin.ua
}

\begin{abstract}
Secondary ion mass spectrometry (SIMS) analysis is used to investigate the composition of surface monolayers of the hydride forming intermetallic TiFe alloy during its interaction with oxygen. Oxygen, which is chemisorbed on the surface, is shown to form strong chemical bonds with both alloy components. As a result, on the surface and in the subsurface region of the alloy, a joint oxide structure forms with a certain stoichiometric ratio between titanium, iron and oxygen. With an increasing partial pressure of oxygen in the oxide structure being formed, the ratio of the number of oxygen atoms to the number of matrix atoms increases. This process occurs uniformly without any abrupt phase transformations.
\end{abstract}

\section{INTRODUCTION}

Hydrogen is an ideal candidate as an energy carrier for both mobile and stationary applications since it has no adverse environmental impact and reduces reliance on non-renewable natural resources [1]. Hydrogen storage, undoubtedly, is one of the key problems in developing hydrogen energy technologies. Hydrogen can be stored as a compressed gas, a cryogenic liquid, and as a chemical compound with materials such as hydride-forming metals or alloys. Using metal hydrides for hydrogen storage has many potential advantages over other storage methods, such as the possibility of achieving ultimately high volumetric densities of hydrogen atoms in the metal lattice; a wide range of working temperatures and pressures; selectivity of hydrogen absorption, ignition-and-explosion safety, and others. All the above factors are the reason of special interest in metal hydrides.

The optimal material for hydrogen storage should have the following properties: high hydrogen capacity per unit mass and volume; low dissociation temperature and a moderate dissociation pressure; low heat of formation; low heat release during exothermal hydride formation, and process reversibility. Moreover, such materials should have limited energy losses during charging and discharging, rapid kinetics, stability against oxygen and moisture influence, cyclability, and low cost and high safety.

To a certain extent, TiFe-based alloys have all these characteristics. They form hydrides with a dissociation pressure close to the atmospheric one at near room temperatures. The hydrogen capacity of the TiFe alloy reaches 1.86 wt.\% at $\mathrm{H} / \mathrm{M}=0.975$ (number of hydrogen atoms per formula unit), with the reversible capacity being $1.5 \mathrm{wt} \%$ [2-4]. The alloy properties are enhanced by the addition of $\mathrm{Mn}, \mathrm{Cr}, \mathrm{Co}, \mathrm{Ni}$, and $\mathrm{V}$. A special advantage of TiFe-based alloys is their low cost and availability of raw materials. The main drawbacks are the necessity of activation, high sensitivity to gas impurities in molecular hydrogen, and a significant hysteresis of absorption-desorption processes [5].

The sensitivity of metal hydrides in general and of the TiFe alloy in particular to gas impurities in molecular hydrogen is a serious problem for their practical application. A fundamental problem to be considered in this regard is surface deactivation with reactive impurities $[6,7]$. Surface deactivation involves degrading of absorption-desorption kinetics and hydrogen capacity reduction when the hydrogen used has reactive impurities. Admixture reactive gases adsorbed on the alloy can dramatically reduce the rate of hydrogen absorption and desorption. Even low impurity concentrations in gaseous hydrogen can induce problems during multiple cycling. Impurities are assumed to form a surface chemical structure that degrades the catalytic properties of a material surface. This hinders the dissociation chemisorption of hydrogen molecules - one of the required stages of hydrogenation.

Considering this, to bring the metal hydrides to a working condition, they, as a rule, must undergo activation treatment such as high-temperature vacuum or hydrogen annealing, or should be treated with highpressure hydrogen for a long time interval. Activation removes the surface chemical structure that prevents dissociation of hydrogen molecules. As regards the TiFe alloy, it shows high affinity to oxygen at high temperatures, and in the majority of cases the passivating layer for the alloy is the surface oxide. TiFe activation requires annealing $(630 \mathrm{~K})$, which removes the surface oxide layer.

However, for the TiFe alloy, as distinct from many other intermetallides, oxygen plays not only a negative role by forming a passivating oxide layer. In some cases, some of the possible alloy oxides do participate in hydration with a positive effect. Many papers have investigated the role of oxygen (oxides) in the dissociative chemisorption of hydrogen as one of the stages of hydride formation.

Thus, paper [8] considers several TiFe activation models. According to one of the models, heat treatment during activation initiates surface segregation. Titanium in the subsurface layer diffuses to the surface and binds the oxygen present in gaseous hydrogen to form titanium oxide $\mathrm{TiO}_{2}$. The excess iron forms an iron cluster in the metallic state. Dissociative chemisorption and associative desorption of hydrogen can occur on such iron particles and on a metal surface free of oxides. 
Hence, the oxygen in this model, by facilitating surface segregation, initiates hydrogen dissociation on the surface as a required hydrogenation stage [9-11].

Paper [12] offers a FeTi activation model that does not involve the formation of catalytically active iron clusters. Alloy annealing in vacuum or hydrogen at low oxygen pressures creates $\mathrm{TiFeO}_{\mathrm{x}}$ regions by dissolution of the initial oxide film in the matrix. Such oxide regions, as the paper indicates, are catalytically active. $\mathrm{TiO}_{2}, \quad \mathrm{Ti}_{\mathrm{n}} \mathrm{O}_{2 \mathrm{n}-1}$, and $\mathrm{Fe}_{7} \mathrm{Ti}_{10} \mathrm{O}_{3}$ regions ensure extra catalytic activity. New catalytic regions on the alloy surface are created continuously owing to material cracking during sorption-desorption cycles. In this model, oxygen and its oxides, under certain conditions, therefore play a positive role.

In general, as regards FeTi alloy oxides, the following can be noted. First, the Fe-Ti-O system allows the coexistence of the FeTi phase with various oxide phases [13]. Second, because of low oxygen solubility in $\mathrm{TiFe}$ and also of the high affinity of titanium-based alloys to oxygen, any mass-produced TiFe alloy contains a significant amount of thermodynamically stable tertiary $\mathrm{Ti}_{4-\mathrm{x}} \mathrm{Fe}_{2+\mathrm{x}} \mathrm{O}_{\mathrm{y}}$ oxides. The precise composition of such oxides depends largely on that of the TiFe alloy and on the annealing and tempering process [14].

Many papers deal with the role of oxides and suboxides in hydride formation processes. Paper [15] demonstrates that surface $\mathrm{Ti}_{4} \mathrm{Fe}_{2} \mathrm{O}_{\mathrm{x}}$ oxides and other oxygen-containing structures are catalytically active towards dissociation of molecular hydrogen. With this in view, as in [12], a model is suggested for activation of TiFe-based alloys. In this model, surface oxides play an active role as distinct from the segregation model where oxides are passive. Paper [16] demonstrates that the $\mathrm{Fe}_{5} \mathrm{Ti}_{7} \mathrm{O}_{2}$ oxide phase absorbs hydrogen along with the FeTi phase. The absorption rate increases due to cracking caused by differential expansion of two phases during heat treatment. The catalytic activity of oxides is confirmed also by various experimental data given in review [17].

Along with papers that consider oxygen and oxide compounds as a fact happening due to the specific features of alloy production or preparation, there are papers where oxygen was intentionally added to TiFe as an additional component. Thus, paper [18] investigated the impact of introducing oxygen $(0.1 \ldots 0.2 \mathrm{wt} . \%)$ to the phase composition of the TiFe alloy. Increasing the oxygen content in the alloy was noted to reduce the content of the basic TiFe phase, along with increasing the content of the mixed $\mathrm{Ti}_{4} \mathrm{Fe}_{2} \mathrm{O}_{1-\mathrm{x}}$ suboxide. Oxygen introduction improved the activation characteristics of the TiFe-based material, but reduced its reversible hydrogen absorption capacity.

Hence, presently, in spite of the large number of studies, no common view exists on the role of oxygen and oxide compounds in the TiFe composition during hydrogen interaction with the alloy. Considering that, information about what occurs on the surface during direct alloy interaction with oxygen would be of interest.

The purpose of the current study is to use SIMS to investigate the composition of the surface monolayers of the intermetallic TiFe alloy during interaction with oxygen, and the changes in this composition depending on the amount of surface oxygen.

\section{RESEARCH METHODS}

The research was conducted using the SIMS technique. The monolithic TiFe alloy samples being investigated were bombarded with primary $\mathrm{Ar}^{+}$ions with an energy of $10 \mathrm{keV}$ when analysing positive secondary ions and with an energy of $18 \mathrm{keV}$ when analysing negative ones. The current density of the primary beam was $9 \ldots 17 \mu \mathrm{A} \cdot \mathrm{cm}^{-2}$, corresponding to the dynamic SIMS mode. Low-energy $(10 \pm 3 \mathrm{eV})$ secondary ions were analysed. The intensities of secondary ion emissions were measured over a dynamic range of at least six orders. The residual vacuum chamber pressure was of order of $10^{-7} \mathrm{~Pa}$.

Prior to measurements, the samples were annealed at $\sim 1100 \mathrm{~K}$ in residual vacuum to partially clean the surface from chemical compounds. Following the annealing, the surface was cleaned with a beam of primary ions until complete stabilisation of the mass spectra and intensity of secondary ion emission was achieved. A gas mass spectrometer was used to control and measure the gas phase composition and the small partial gas pressures in the vacuum chamber. While analysing the emission of polyatomic secondary ions that characterise the composition of surface compounds, and in a complicated way overlap by their mass numbers, their specific contributions were separated according to a typical procedure using the natural abundance of isotopes.

\section{EXPERIMENTAL RESULTS AND DISCUSSION}

The measurements of the mass spectra of positive and negative secondary ions sputtered off the cleaned TiFe surface demonstrated the presence of a large amount of emissions attributed to both the alloy material and its impurities, and to objects introduced from the gas phase. Mass spectra contain atomic cluster ions, as well as intermetallic titanium and iron ions. The spectrum also includes various emissions that correspond to compounds of matrix atoms with hydrogen, oxygen and carbon. Such emissions in the spectrum suggest that, in the experimental conditions specified, i.e. even following annealing and cleaning with the primary beam, chemical compounds are found on the surface of alloy samples. These compounds include oxides, hydrides, hydroxides and carbides of alloy components. Oxygen chemisorption on the TiFe surface gives rise to a large amount of oxygencontaining secondary ions of alloy components in the mass spectra. This is indicative of the formation of oxide compounds on the surface and subsurface region. To track how the composition of these compounds varies with changes in the amount of oxygen the following was done. The dependences of the emission intensities of oxygen-containing secondary ions on the oxygen partial pressure in the sample chamber were measured. The oxygen pressure was within the range $1.2 \cdot 10^{-6} \ldots 6.6 \cdot 10^{-4} \mathrm{~Pa}$ The hydrogen partial pressure remained at residual $\sim 1 \cdot 10^{-6} \mathrm{~Pa}$. In the following 
Figs. 1-4 the examples of such dependencies measured at a room temperature are shown. The current density of primary ions was $9 \mu \mathrm{A} \cdot \mathrm{cm}^{-2}$ when measuring positive secondary ions and $17 \mu \mathrm{A} \cdot \mathrm{cm}^{-2}$ when measuring negative ones.

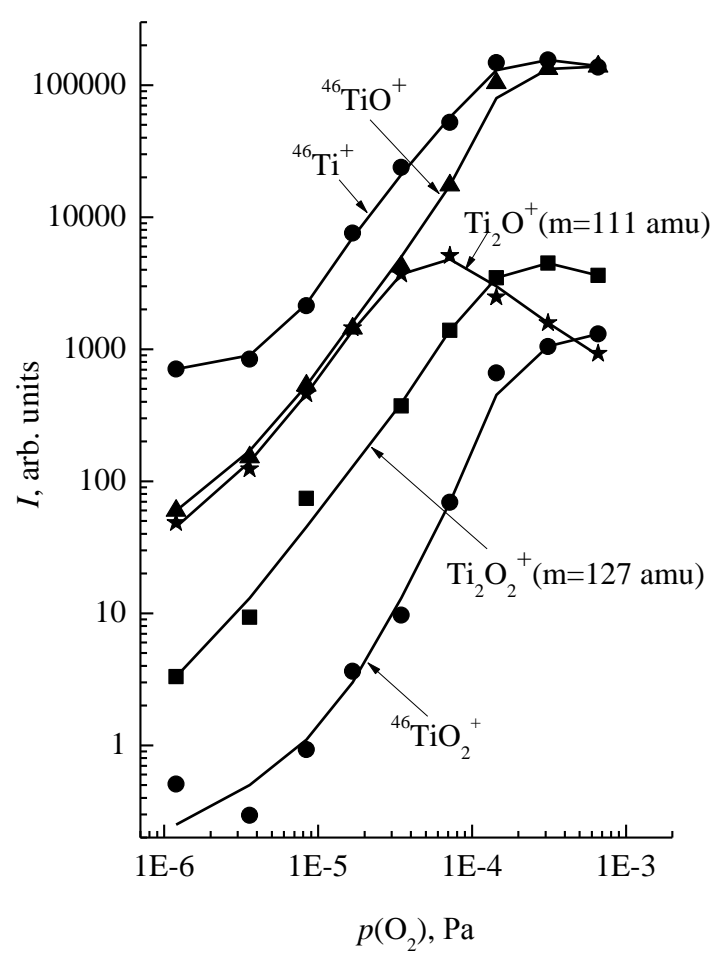

$a$

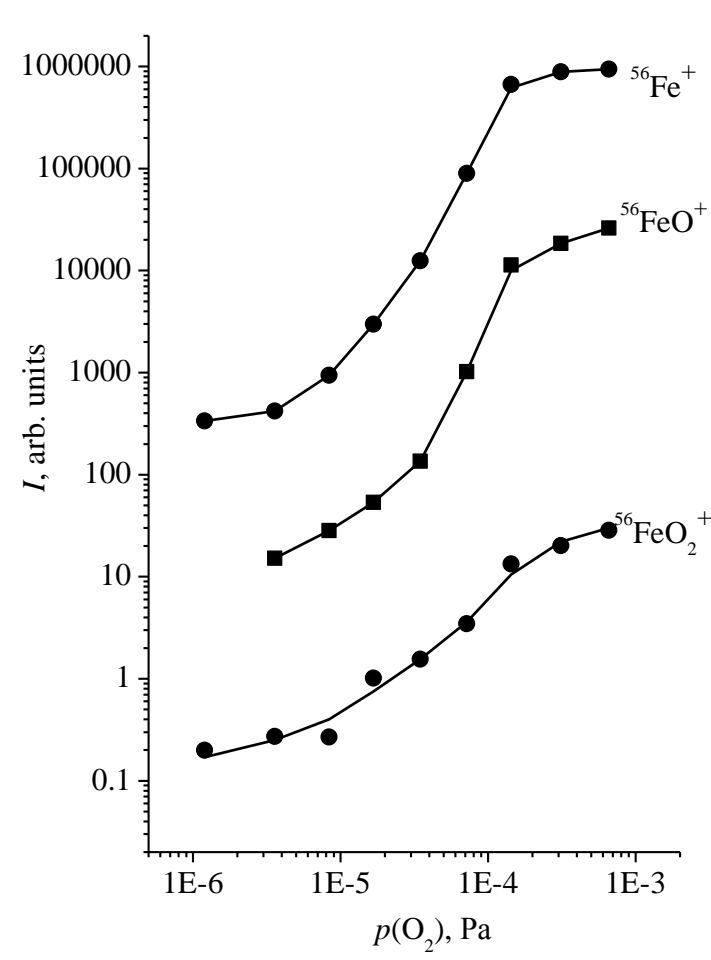

$b$

Fig. 1. Dependences of the emission intensity of positive oxygen-containing secondary ions on the oxygen partial pressure: $a$-ions with titanium; $b$-ions with iron

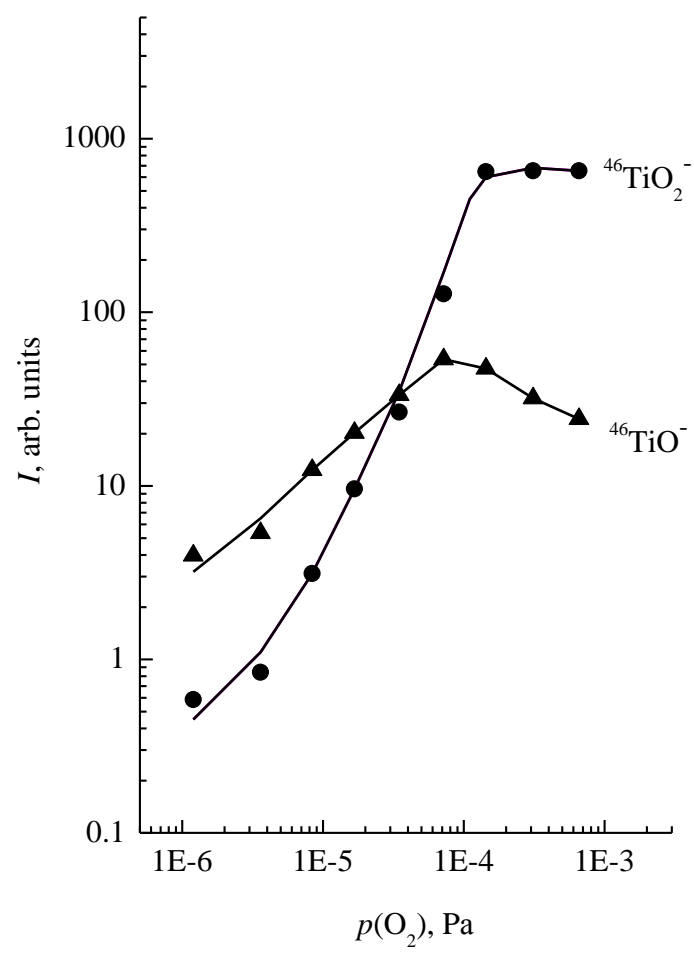

$a$

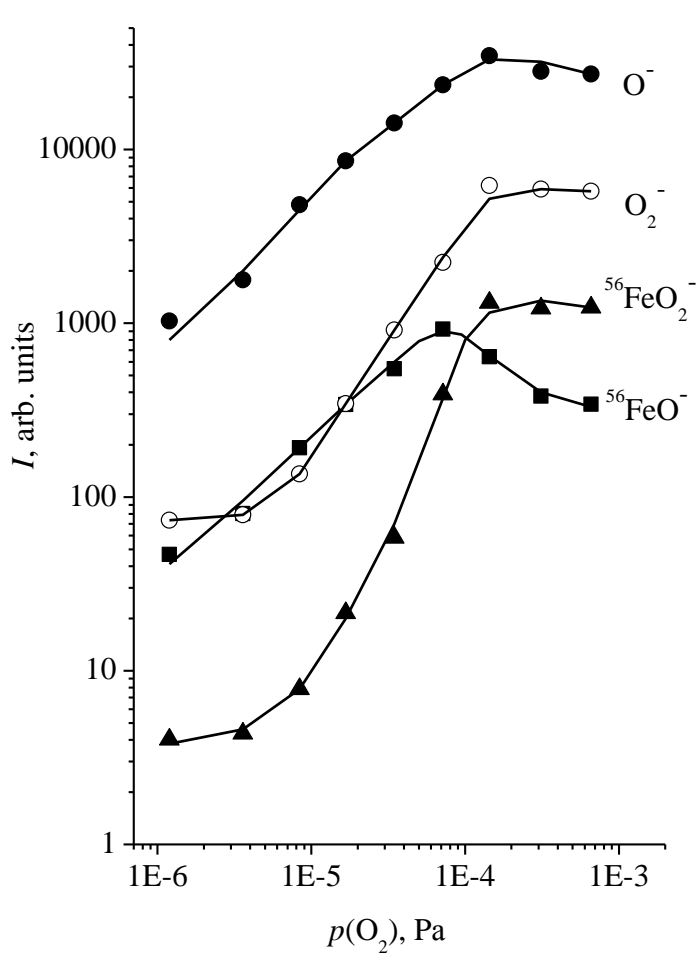

$b$

Fig. 2. Dependences of the emission intensity of negative oxygen-containing secondary ions on the oxygen partial pressure: $a$-ions with titanium; $b$-ions with iron 


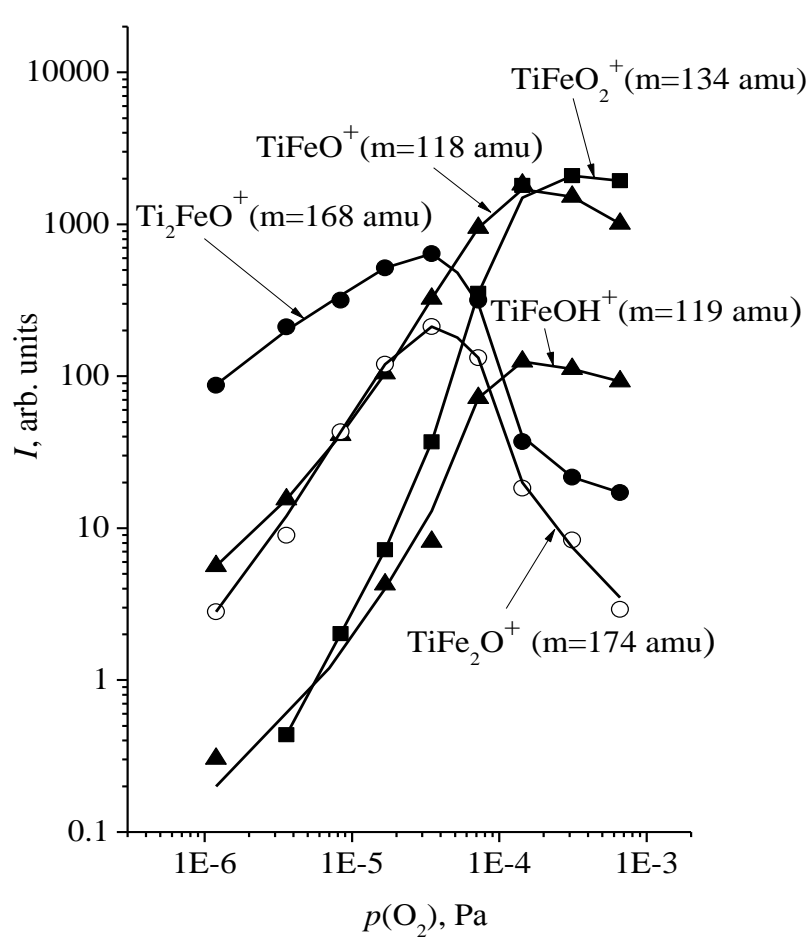

Fig. 3. Dependences of the emission intensity of positive oxygen-containing secondary ions with titanium and iron on the oxygen partial pressure

Analysis of results demonstrates the following. Increase of oxygen partial pressure in the sample chamber leads to emergence of emission of a variety of oxygen-related secondary ions of alloy components, such as $\mathrm{TiO}_{\mathrm{m}}{ }^{ \pm}(\mathrm{m}=1,2) ; \mathrm{Ti}_{2} \mathrm{O}_{\mathrm{m}}{ }^{+}(\mathrm{m}=1,2,3) ; \mathrm{Ti}_{3} \mathrm{O}_{\mathrm{m}}{ }^{+}$ $(\mathrm{m}=1,2) ; \mathrm{FeO}_{\mathrm{m}}{ }^{ \pm}(\mathrm{m}=1,2,3) ; \mathrm{Fe}_{2} \mathrm{O}_{\mathrm{m}}{ }^{+}(\mathrm{m}=1,2,3)$. In addition, there is a large number of oxygen-containing emissions of complex secondary ions containing titanium, iron and oxygen atoms in different ratios of the type $\mathrm{TiFeO}_{\mathrm{m}}{ }^{+}(\mathrm{m}=1,2,3) ; \mathrm{Ti}_{2} \mathrm{FeO}_{\mathrm{m}}{ }^{+}(\mathrm{m}=1,2,3)$; $\mathrm{TiFe}_{2} \mathrm{O}_{\mathrm{m}}{ }^{+}(\mathrm{m}=1,2)$. Along with the emission of ions of oxides, the spectra have respective emissions of ions of hydroxides and hydrides.

Intensive emissions of oxygen-containing ions with titanium and iron at elevated oxygen partial pressures are direct indication that adsorbing on the alloy surface oxygen forms strong chemical bonds with titanium and iron. The presence of complex titanium-iron ions indicates that, on the surface and in the subsurface region, a common oxygen-containing structure is formed with a definite stoichiometric ratio between titanium, iron and oxygen. The nature of such a structure is characterised by both an ensemble of oxygen-containing positive and negative secondary ions, and the ratio of their emission intensities. With increasing oxygen pressure, the emission intensity increases for the majority of oxygen-containing secondary ions (see Figs. 1, 2). For some secondary ions, in particular, ions with a low ratio of the number of oxygen atoms and the number of metal atoms, e.g., $\mathrm{Ti}_{2} \mathrm{FeO}^{+}$and $\mathrm{TiFe}_{2} \mathrm{O}^{+}$, the pressure dependencies pass through a maximum.

Hence, with an increasing oxygen partial pressure, an oxide structure with a certain stoichiometric ratio between titanium, iron and oxygen is formed on the surface and in the subsurface region of the sample. Since the measured oxygen pressure dependencies have no specific features such as steps or inflections, this suggests that oxide compounds are formed uniformly without any phase transformations. With increasing oxygen partial pressure, the number of oxygen atoms per matrix atom increases in the oxide structure being formed, i.e. there is a transition from oxygen-depleted oxides to oxides with a bigger specific amount of oxygen. The transition occurs successively as oxygen is accumulated. As a result, oxides are formed on the surface and in the subsurface region. As shown in [15-18], they are catalytically active in the processes of dissociative chemisorption of hydrogen. Probably, such properties to a greater or lesser extent are inherent to oxides with a different stoichiometric ratio of components. This is what accounts for the big variety of specific compositions of oxides that play a positive role in hydrogenation processes investigated in many experiments. Naturally, such positive properties are manifested until the oxide composition, as per relative amount of oxygen, remains catalytically active or until the thickness of the oxide coating becomes critical for hydrogen sorption-desorption.

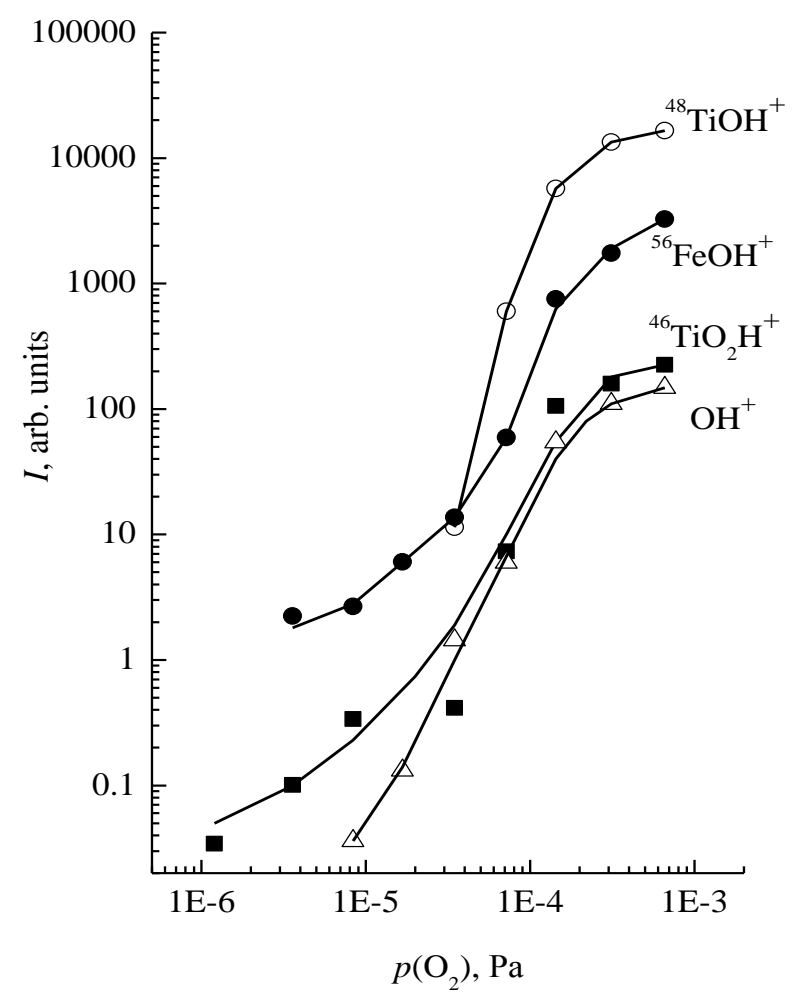

Fig. 4. Dependences of the emission intensity of positive secondary ions of hydroxides with titanium and iron on the oxygen partial pressure

Note that the amount and composition of oxides on the surface being investigated in our case is the result of the simultaneous action of several processes, namely oxygen chemisorption from the gas phase and primary beam sputtering. Surface desorption processes may also contribute here.

Fig. 4 shows the emission intensities of positive secondary ions of hydroxides with titanium and iron sputtered off the TiFe surface depending on partial oxygen pressure. The emission of hydroxide ions is 
caused by both interaction with residual hydrogen of the gas phase and residual hydrogen in the sample volume. The dependences of the intensity of emission of such ions on oxygen partial pressure correlate in principle with the dependencies for the oxide ions.

Unfortunately, in our investigations a great number of emissions of complex polyatomic oxygen-containing secondary ions with low intensity overlap by mass numbers in an intricate way. Separation of their contributions using a typical procedure, using the natural abundance of isotopes, can introduce a serious error. For instance, the oxide $\mathrm{Ti}_{4} \mathrm{Fe}_{2} \mathrm{O}_{1-\mathrm{x}}(0<\mathrm{x}<1)$, being in the focus of interest of several investigators and assumed to be catalytically active with respect to decomposition of molecular hydrogen, has a mass number range of $299 . . .324 \mathrm{amu}$. In our case, the mass spectrum of positive ions in this mass range has some emissions. But the oxides $\mathrm{Ti}_{3} \mathrm{Fe}_{2} \mathrm{O}_{3}$ and $\mathrm{Ti}_{2} \mathrm{Fe}_{3} \mathrm{O}_{2}$ also correspond to this range. It is impossible to separate these emissions with adequate accuracy. Hence, though polyatomic oxygen-containing secondary ions characterise to the utmost the composition of chemical compounds on the surface and in the subsurface region, as regard these ions, one can ascertain only their presence.

\section{CONCLUSIONS}

SIMS analysis of the chemical composition of surface monolayers of the hydride-forming intermetallic TiFe alloy during interaction with oxygen has shown the following. Under oxygen exposure, oxygen-containing compounds composed of both alloy components are formed on the surface and in the subsurface region of the TiFe sample. This is evidenced by the presence of secondary ions of titanium with oxygen and of iron with oxygen, as well as by the presence of secondary ions composed of titanium and iron and oxygen. The emission of such ions directly indicates that oxygen, which is chemisorbed on the surface, forms strong chemical bonds with both alloy components. Hence, a common oxide structure with a certain stoichiometric ratio between titanium, iron and oxygen is formed on the surface and in the subsurface region of the alloy.

With the increase of oxygen partial pressure, the emission intensities of the majority of oxygencontaining secondary ions also increase. The measured dependences reflect the process of increasing the ratio of the number of oxygen atoms to the number of matrix atoms in the oxide structure being formed. This process occurs uniformly without any abrupt phase transformations.

\section{REFERENCES}

1. B. Sakintuna, F. Lamari-Darkrim, M. Hirscher. Metal hydride materials for solid hydrogen storage: A review // Int. J. Hydrogen Energy. 2007, v. 32, issue 9, p. 1121-1140.

2. J.J. Reilly, R.H. Wiswall. Formation and properties of iron titanium hydride // Inorg. Chem. 1974, v. 13, N 1, p. 218-222.
3. G. Sandrock. A panoramic overview of hydrogen storage alloys from a gas reaction point of view // $J$. Alloy Compd. 1999, v. 293-295, p. 877-888.

4. Б.А. Колачев, Р.Е. Шалин, А.А. Ильин. Сплавь-накопители водорода: Справ. изд. М.: «Металлургия», 1995, 384 с.

5. D.G. Ivey, D.O. Northwood. Storing energy in metal hydrides: a review of the physical metallurgy // $J$. Mater. Sci. 1983, v. 18, N 2, p. 321-347.

6. G.D. Sandrock, P.D. Goodell. Surface poisoning of $\mathrm{LaNi}_{5}$, FeTi and (Fe, Mn)Ti by $\mathrm{O}_{2}$ and $\mathrm{H}_{2} \mathrm{O} / /$ J. LessCommon Met. 1980, v. 73, p. 161-168.

7. F. Schweppe, M. Martin, E. Fromm. Hydrogen absorption of $\mathrm{LaN}_{\mathrm{i} 5}$ powders precovered with $\mathrm{O}_{2}, \mathrm{CO}$, $\mathrm{H}_{2} \mathrm{~S}, \mathrm{CO}_{2}$ or $\mathrm{N}_{2} / /$ J. Alloys Compd. 1997, v. 253-254, p. 511-514.

8. H.C. Kim, Jai-Young Lee. The effect of surface conditions on the activation of FeTi // J. Less-Common Met. 1985, v. 105, p. 247-253.

9. L. Schlapbach, A. Seiler, F. Stucki, H.C. Siegmann. Surface effects and the formation of metal hydrides // J. Less-Common Met. 1980, v. 73, p 145-160.

10. L. Schlapbach, A. Seiler, F. Stucki. Surface segregation in FeTi and its catalytic effect on the hydrogenation // Mat. Res. Bul. 1978, v. 13, issue 7, p. 697-706.

11. H. Zuchner, U. Bilitewski, G. Kirch. Auger electron spectroscopy and secondary ion mass spectrometry investigations of the activation of TiFe for hydrogen uptake // J. Less-Common Met. 1984, v. 101, p. 441-451.

12. T. Schober. On the activation of FeTi for hydrogen storage // J. Less-Common Met. 1983, v. 89, p. 63-70.

13. W. Rostoker. Selected isothermal sections in the titanium-rich corners of the systems Ti-Fe-O, Ti-CrO, and Ti-Ni-O // J. of Metals. 1955, v. 7, issue 1, p. 113-116.

14. B. Rupp. On the change in physical properties of $\mathrm{Ti}_{4-x} \mathrm{Fe}_{2+x} \mathrm{O}_{y}$ during hydrogenation I: Activation behaviour of ternary oxides $\mathrm{Ti}_{4-x} \mathrm{Fe}_{2+x} \mathrm{O}_{y}$ and $\beta$-Ti // J. Less-Common Met. 1984, v. 104, p. 51-63.

15. V.D. Dobrovolsky, S.N. Yendrzheevskaya, A.K. Sinelnichenko, V.V. Skorokhod, O.Yu. Khyzhun. Analysis of the surface condition of $\mathrm{Ti}_{4} \mathrm{Fe}_{2} \mathrm{O}_{\mathrm{x}} / /$ Int. J. Hydrogen Energy. 1996, v. 21, issue 11-12, p. 10611064.

16. T. Matsumoto, M. Amano. The hydriding of FeTi during an activation treatment by in-situ x-ray diffraction // Scripta metallurgica. 1981, v. 15, p. 879883.

17. L. Schlapbach, T. Riesterer. The activation of FeTi for hydrogen absorption // Appl. Phys. A. 1983, v. 32, p. 169-182.

18. M.W. Davids, M. Lototskyy. Influence of oxygen introduced in TiFe-based hydride forming alloy on its morphology, structural and hydrogen sorption properties // Int. J. Hydrogen Energy. 2012, v. 37, issue 23, p. 18155-18162. 


\section{ВИМС-ИССЛЕДОВАНИЕ ВЗАИМОДЕЙСТВИЯ СПЛАВА ТіFе С КИСЛОРОДОМ}

\section{В.А. Литвинов, И.И. Оксенюк, Д.И. Шевченко, В.В. Бобков}

Методом вторичной ионной масс-спектрометрии (ВИМС) проведено исследование состава поверхностных монослоев гидридообразующего интерметаллического сплава ТіFе при взаимодействии с кислородом. Показано, что кислород, который хемосорбируется на поверхности, образует прочные химические связи с обоими компонентами сплава. В результате на поверхности и в приповерхностной области сплава реализуется общая оксидная структура с определенным стехиометрическим соотношением между титаном, железом и кислородом. По мере увеличения парциального давления кислорода в образующейся оксидной структуре отношение количества атомов кислорода к количеству атомов матрицы увеличивается. Этот процесс происходит равномерно, без каких-либо фазовых трансформаций.

\section{ВІМС-ДОСЛІДЖЕННЯ ВЗАСМОДІЇ СПЛАВУ ТіFе 3 КИСНЕМ}

\section{В.О. Литвинов, І.І. Оксенюк, Д.І. Шевченко, В.В. Бобков}

Методом вторинної іонної мас-спектрометрії (BIMC) проведене дослідження складу поверхневих моношарів гідридоутворюючого інтерметалевого сплаву TiFe при взаємодії з киснем. Показано, що кисень, який хемосорбується на поверхні, утворює міцні хімічні зв'язки з обома компонентами сплаву. У результаті на поверхні і в приповерхневій області сплаву реалізується загальна оксидна структура 3 певним стехіометричним співвідношенням між титаном, залізом і киснем. У міру збільшення парціального тиску кисню в оксидній структурі, що утворюється, відношення кількості атомів кисню до кількості атомів матриці збільшується. Цей процес відбувається рівномірно, без яких-небудь фазових трансформацій. 